\title{
Employee and Organizational Performance: Impact of Employee Internal and External Factors, Moderated by Online Application
}

\author{
Deden Tarmidi Regina Jansen Arsjah \\ Faculty of Economic and Business, Universitas Trisakti, Jl. Kyai Tapa No. 1, Grogol, Jakarta Barat 11440
}

\begin{abstract}
The purpose of this study is analyze the internal factors impact of an employee (especially age, discipline, and motivation), and external factors of employee (especially training and incentives) on employee performance and organizational performance. The moderation impact of online application also analized at the relationship between employee performance on organizational performance. Used taxi drivers as unit analysis is an uniqueness of this study, the snowballing method with e-questionnaire used for collecting data resulted 100 taxi drivers as a sample. Using SmartPLS 3 in analyze, the results showed that the driver's motivation as a part of internal employee factors has a positive impact on employee performance directly and on organizational performance indirectly. Employee performance has a positive impact on organizational performance. The result implies that the company should always increase the driver's motivation for performance increased also. The other result showed that online application weakens the relationship between employee performance and organizational performance. Based on thus result, management needs to seek solutions.
\end{abstract}

Keywords: Employee Internal Factors, Employee External Factors, Employee Performance, Organizational Performance, Online Application

DOI: $10.7176 / J R D M / 57-04$

Publication date:July $31^{\text {st }} 2019$

\section{Introduction}

Transportation is very important for business operational, that used for move goods and people. Congestion in many cities in the world, including Jakarta cause the reluctance of vehicle owners to use theirs in their daily routine, then public transportation services like taxi are one of alternative. History records that Daimler Victoria Taxi is first taxi in the world arround 1897 while taxi in Indonesia first operation in 1930. The Central Bureau of Statistics (BPS) reported that the growth of transportation corporate in Indonesia was quite rapid. This was evident from the registration of several transportation companies on the IDX like Blue Bird.

Blue Bird is one of the largest transportation corporates in Indonesia. With "ANDAL" standard service, every driver is trained to give the great service to passanger. The image of excellent service is a part of the company's performance and made BIRD growth. The driver is the most important in growth of taxi company because driver is front of sales service. Thus, the quality of each driver is important for driver performance and organizational performance (Kleinknecht, 2014; Vosloban, 2012; Hatane, 2015).

As an individual, each driver is unique in terms of age, discipline, and motivation. This uniqueness can have an impact on performance (Mullen et al., 2017; Groen et al., 2016; Gellert \& Schalk, 2012; Pawirosumarto, 2017) and organizational performance (O'Hagan, 2017)

As the biggest taxi company in Indonesia, Blue Bird has a good system in human development. Training and incentive are part of any system in the company. Kumara \& Utama (2016), Baht (2013), Khan et al., (2014), Hameed et al. (2014) and Triasmoko et al. (2014) found that training and incentive have an impact on employee performance, while Anyango \& Muathe (2017) and Aragon et al. (2014) found that training and incentive have an impact on organizational performance.

Blue Bird's growth began to have problems when other online transportation application such as "Gojek," "Grab" and "Uber" appeared in a few last years (Afriyadi, 2017, Liputan6.com). Blue Bird share value and company performance go down since listing on the capital market. 
Figure 1 - Performance and Value of BIRD

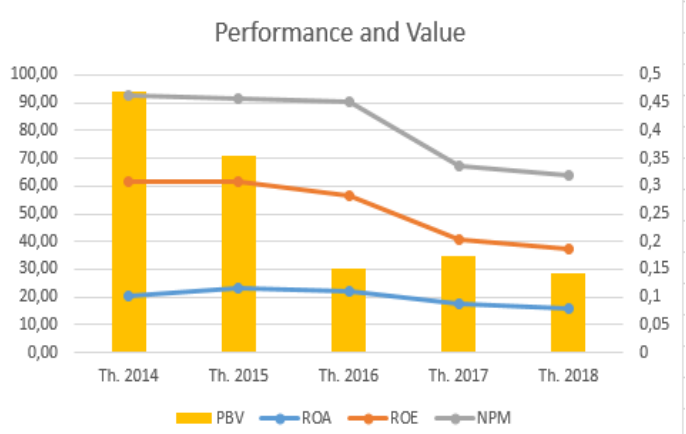

Figure 2 - Total Taxi \& Revenue

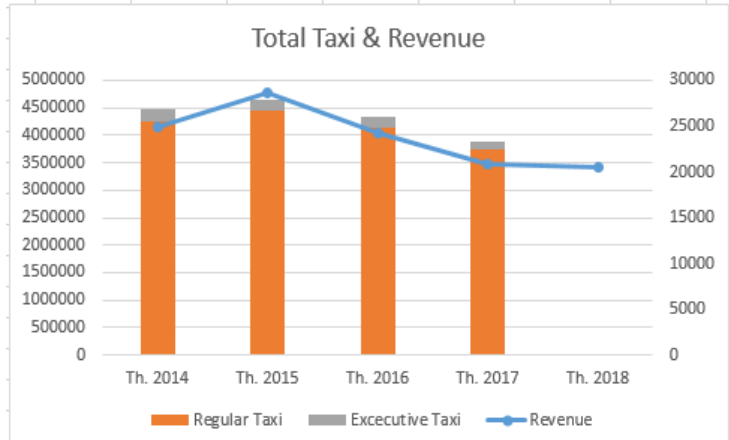

Passengers prefer to use taxi online because of the ease and benefit of the online application, which is in line with the Technology Acceptance Model (TAM) Theory by Davis (1986).

Figure 2 showed that revenue from the taxi business (regular and executive) went down since 2014. The decrease in taxi company revenue meant the decrease of taxi drivers. Then Blue Bird began to use the application "My Bird" and collaborating with "Gojek" through the "Go Bird" service. The using of "My Bird" is expected to improve company performance (Pfano \& Beharry, 2016). However, how is the perception of taxi driver about using this application? Does it improve company performance?

\section{Literature Review}

\subsection{Theoretical Framework}

2.1.1. Social Psychology of Organization

In his book "The Human Side of Enterprise" McGregor explains the theory X and the theory Y where the theory $\mathrm{X}$ is used by managers who lead employees to work according to direction, while in theory $\mathrm{Y}$ manager entrust employees to work according to his way. While Hezberg (1964) describes the theory of motivation that a person on the job base on two things: job satisfaction and job dissatisfaction. The measure of job satisfaction is from how long someone is doing a job, the more satisfied someone in work allegedly the longer his working life. Moreover, Vrom (1964) in the theory of expectation explains that a person is motivated to do something to achieve a certain goal.

In theory $\mathrm{Y}$, the theory of motivation and the theory of expectation known that employees, in this case, the driver, can improve company performance directed or targeted company in its way and internal factors possessed both ages, gender, education, discipline and motivation it has. While the theory $\mathrm{X}$ to this research is where the performance of the driver personally also influenced by external factors received from organizations such as training, direct compensation and indirect compensation.

2.1.2. Technology Acceptance Model

In the Technology Acceptance Model from Davis (1986) described that someone uses technology due to various reasons such as perceptions about the ease of use of these technologies and the perception of the usefulness of these technologies. The use of online transportation on taxi drivers in Indonesia certainly has specific reasons as well as passengers who also use the application. With the use of online transport applications, drivers do not need to find passengers on the roadside, but just waiting for an order from prospective passengers then the online application implementation strategy can affect organizational performance (Torres et al., 2014; Gidumal \& Gonzalez, 2011).

\subsection{Conceptual Framework and Hypothesis Development}

\subsubsection{Employee Internal Factors on Performance}

As a personality, each employee has their uniqueness, and some research finds the uniqueness of each has a relationship and influence on the individual performance or organization where the employee works.

Mullen et al. (2017) found that a person's age was influential in controlling safety in work and controlling his performance (Groen et al., 2016). Older employees will perform better because they are more experienced in interacting with their superiors (Gellert \& Schalk, 2012).

Hla. Age has a positive impact on employee performance

$H 1 b$. Age has a positive impact on organizational performance by employee performance.

A person's motivation in working can affect his or her performance as well as discipline in work (Pawirosumarto et al., 2017; Nabi et al., 2017; Nadeem et al., 2014; Prophet et al., 2017) and also on organizational performance (Dobre, 2013). Referring to the theory of motivation and the theory of expansion that when a person has a certain purpose, then he will work well and achieve his goals can be achieved.

H2a. Discipline has a positive impact on employee performance 
H2b. Discipline has a positive impact on organizational performance by employee performance

H3a. Motivation has a positive impact on employee performance

H3b. Motivation has a positive impact on organizational performance by employee performance.

2.2.2 Employee External Factors on Performance

As a social being, a person always needs and needs by others, as well as in work. An employee is needed by the organization to be able to run under the vision of the mission and objectives of the organization, on the other hand, the employees also need support from the company in order to work according to company goals (Sudibyo \& Hiskia, 2013).

If the level of education is an internal factor that is the basis of employee knowledge, then training or more precisely on the job training provided by the company is one factor that affects the performance of employees (Salem \& Abdien, 2017; Kumara \& Utama, 2016; Bhat, 2013, Sharma, 2016, Triasmoko et al., 2014; Al-Mzary, 2015) and company performance (Aragon et al., 2014; Ayango \& Muathe, 2017; Athar \& Shah, 2015). Training is one's activity in improving systematic skills and knowledge to have good performance in its field (Eko, 2015) and organizational effectiveness happening well (Falola et al., 2014)

H4a. Training has a positive impact on employee performance.

H4b. Training has a positive impact on organizational performance by employee performance.

Incentives, salaries or rewards from companies are external factors that employees receive and influence personal performance (Groen et al., 2016; Hameed et al., 2014; Panjaitan, 2015; Atambo et al., 2013; Al-Belushi \& Khan, 2017).

H5a. Incentive as a positive impact on employee performance

$H 5 b$. The incentive has a positive impact on organizational performance by employee performance 2.2.3 Employee Performance on Organizational Performance

The difference in the character of the internal factor of employees have a different impact also on the performance of the employees themselves and because employees is a part of the organization then employee performance impact on organization performance (Hatane, 2015; Vosloban, 2012).

H6. Employee Performance has a positive impact on organizational performance

2.2.4 Implementation of Online Application has Moderating impact Employee Performance on Organizational Performance

The use of technology in the business has grown in line with the ease and benefits enjoyed by its users, including online applications in the field of transportation enjoyed by passengers, drivers and also increases of organization performance (Pfano \& Beharry, 2016).

H7. Implementation of the online application to strengthen the impact of Employee Performance on Organizational Performance

\section{Methodology}

3.1 Population and Sample

23.000 taxi drivers of Blue Bird in Indonesia (www.bluebirdgroup.com) became population and unit of analysis in this study. Snowballing method with e-questionnaire by link used in sampling because the amount of taxi driver blue bird in Jakarta each not known and drivers were not at the office but on the way every time. 104 Questionnaire received back from respondents, but only 100 data can be analyzed because the others not complete and filled by the same person. Linkert scale 1-6 used in the questionnaire for filled by respondent.

\subsection{Operational Variable}

The measurement of previous research has been adopted in each variable of this study, the use of Employee Performance as an intervening variable and Implementation of Online Applications as a moderating variable is a novelty of this study.

Organizational performance is a situation where the organization in increasing income and profit which is the result of the performance of employees, especially taxi drivers as the backbone of the company. Researchers asked about the driver's opinion of the company compared to other similar companies (Torres et al., 2014) with a Likert scale of 1-6 in particular about the three dimensions adopted from Marques (2003) are Economic, Relational and Adaptive. In this study, economic measured by (1) revenue and (2) brand, relational measured by (3) order frequency, (4) service of the passenger, while adaptive measured by (5) product differentiation and (6) service innovation.

Employee performance is a condition where Driver has good performed his duties in delivery with the determined quality of service. The 3 dimensions used in measuring employee performance are (1) Amount of Effort and (2) Quality of Effort modified from Alfandi \& Alkansawneh (2014) and Pawirosumarto at al. (2017) which makes staff as unit analysis and (3) Decreasing Stress adopted from Gellert \& Schalks' (2012).

Employee internal factors are a personal factor of the driver attached to the personal and allegedly affect the performance. Adopted from Groen et al. (2016) and Gellert \& Schalk (2012), Age measured by (1) wise and (2) 
experience. Discipline measured by (1) absent, (2) early leaving, and (3) coming late are modified from Pawirosumarto et al. (2017) which makes office and factory employee as unit analysis. Then motivation measured by (1) Comfortable life, and (2) Avoid difficult life are adopted from Pawirosumarto et al. (2017) and Khan et al. (2014)

While the employee's external factors in this study are something that is given by the company to employees were measured by training and incentive. In this study, Training measured by two dimensions is (1) first training, and (2) development are adopted from Sharma (2016) and Falola et al. (2014). While incentive measured by (1) commission, (2) bonus, and (3) health allowance, are adopted from Hameed et al. (2014) and Al-Belushi \& Khan (2017). The implementation of the online transport application as a moderating variable is measured by the driver's perception of (1) easy and (2) use according to TAM of Davis (1989) and ETAM from Sicotte (2015) described by Taherdoost (2018).

\subsection{Hypothesis Testing Method}

The Structural Equation Model used in this tudy and analyzed by SmartPLS 3 with validity analysis by outer loading factor and AVE and reliability analysis by Composite Reliability and Cronbach's alpha and also analysis amount of adjust r-square. The inner model analysis used for see amount of impact exogenous variables on endogen variables including intervening and moderating variables.

\section{Result and Discussion}

4.1 Characteristic Respondent

There five questions of respondents' profile in a questionnaire are Taxi driver number, Age, Gender, Handphone number, Last Education. Taxi Driver Number and Handphone number are different for each respondent because it is not analyzed and for the other will analyzed here.

From 100 respondents the gender all is male and respondent with age between 30 years old up to 40 years old is highest while respondent with age older than 55 years old is lowest. Senior high school is respondents' last education highest while the lowest is the elementary school.

\subsection{Descriptive Analysis}

Table 1. Descriptive Statistics of Variables

\begin{tabular}{lrr}
\hline \multicolumn{1}{c}{ Variables } & \multicolumn{1}{c}{ Mean } & Std. Deviation \\
\hline \hline X1.Age & 5,3650 & 1,2569 \\
X2.Discipline & 5,2400 & 1,5396 \\
X3.Motivation & 5,6900 & 0,9994 \\
X4.Training & 5,3150 & 1,3948 \\
X5.Incentive & 5,3733 & 1,3466 \\
Z1.Employee Performance & 5,6862 & 0,9843 \\
Z2.Implementation Online Application & 5,6225 & 1,1149 \\
Y. Organizational Performance & 5,7267 & 1,0101 \\
\hline
\end{tabular}

With the amount of Mean for each variable in the range 5 and more than Std. Deviation amount that respondents have a good perception of each questionnaire.

\subsection{Goodfit Analysis}

Table 2. Goodness of fit Analysis

\begin{tabular}{lrcccr}
\hline \multicolumn{1}{c}{ Var } & Loading Factor & AVE & $\begin{array}{c}\text { Composite } \\
\text { Reliability }\end{array}$ & $\begin{array}{c}\text { Croncbach's } \\
\text { Alpha }\end{array}$ & $\begin{array}{c}\text { Adj. R- } \\
\text { square }\end{array}$ \\
\hline \hline $\mathrm{Ag}$ & $0,937-0,956$ & 0,896 & 0,945 & 0,885 & - \\
$\mathrm{Di}$ & $0,780-0,857$ & 0,684 & 0,866 & 0,784 & - \\
$\mathrm{Mo}$ & $0,972-0,972$ & 0,945 & 0,972 & 0,942 & - \\
$\mathrm{Tr}$ & $0,903-0,919$ & 0,830 & 0,907 & 0,795 & - \\
$\mathrm{Inc}$ & $0,856-0,937$ & 0,821 & 0,932 & 0,891 & - \\
$\mathrm{EP}$ & $0,805-0,975$ & 0,862 & 0,974 & 0,967 & 0,844 \\
$\mathrm{IOA}$ & $0,966-0,989$ & 0,954 & 0,988 & 0,984 & - \\
OP & $0,871-0,988$ & 0,921 & 0,986 & 0,983 & 0,965 \\
\hline
\end{tabular}

Note: $\mathrm{Ag}=\mathrm{Age}, \mathrm{Di}=$ Discipline, $\mathrm{Mo}=$ Motivation, $\mathrm{Tr}=$ Training, $\mathrm{Inc}=$ Incentive, $\mathrm{EP}=\mathrm{Employee}$

Performance, $\mathrm{IOA}=$ Implementation of Online Application, OP=Organizational Performance

Table 2 that the model is valid because the amount of factor loading each indicator is more than 0,7 and amount of AVE (Average Variance Extracted) is more than 0,5. The model is also reliable because the amount of 
composite reliability is more than 0,7 and amount of Cronbach's alpha also more than 0,7 (Ghozali \& Latan, 2015; Chin, 2010; Chin, 1998; Hair et al., 2012; Hair et al., 2011). The amount of adjusted R-Square is also good with amount 0,816 and 0,957 for Organizational Performance.

4.4 Hypothesis result

Table 3. Hypothesis Result

\begin{tabular}{|c|c|c|c|c|c|c|}
\hline Direct & Indirect & Prediction & Original Estimate & P Values & Sig & Result \\
\hline \multirow[t]{2}{*}{$\mathrm{Ag}->\mathrm{EF}$} & & + & 0,093 & 0,187 & & \\
\hline & $\mathrm{Ag}->\mathrm{EP}->\mathrm{OP}$ & + & 0,089 & 0,181 & & \\
\hline \multirow[t]{2}{*}{ Di -> EP } & & + & 0,149 & 0,149 & & \\
\hline & Di $->$ EP $->$ OP & + & 0,143 & 0,143 & & \\
\hline \multirow[t]{2}{*}{ Mo -> El } & & + & 0,648 & 0,000 & $* * *$ & Accepted \\
\hline & Mo -> EP-> OP & + & 0,622 & 0,000 & $* * *$ & Accepted \\
\hline \multirow[t]{2}{*}{$\operatorname{Tr}->$ EP } & & + & $-0,037$ & 0,725 & & \\
\hline & $\mathrm{Tr}->\mathrm{EP}->\mathrm{OP}$ & + & $-0,035$ & 0,720 & & \\
\hline \multirow[t]{2}{*}{ Inc $->$ EP } & & + & 0,165 & 0,116 & & \\
\hline & Inc $->\mathrm{EP}->\mathrm{OP}$ & + & 0,158 & 0,110 & & \\
\hline $\mathrm{EP}->\mathrm{OH}$ & & + & 0,960 & 0,000 & $* * *$ & Accepted \\
\hline $\mathrm{EP} * \mathrm{IO}$ & $->$ OP & + & $-0,171$ & 0,002 & $* *$ & \\
\hline
\end{tabular}

Table 3 explained that from 12 hypotheses only three accepted, motivation has a positive impact on employee performance directly and also on organizational performance indirectly, that in line with Nabi et al. (2017), Khan et al., (2014), Pawirosumarto et al. (2017). Employee performance has a positive impact on organizational performance, in line with a prior study from Vosloban (2012). Implementation online application honestly has a significant moderating in impact employee performance on organizational performance, but because the impact is contrary, the hypothesis is rejected.

The result explains that employee performance especially driver taxi as direct marketing in a taxi company is very important on organizational performance, a great motivation who had by the taxi driver is very high impact on the development of taxi company like Blue Bird.

The other result is that online implementation application in the service of Blue Bird taxi has a negative impact on the performance as an individual and indirect impact on the company. In some interviews with drivers, some drivers do not like using transportation online because passengers able to self-cancel the orders, and there are fake orders. Some drivers became an online car driver. This result can be information, why BIRD's performance goes down a few last years.

\subsection{Discussion}

Motivation has a positive impact on employee performance directly, and on organizational indirectly, employee performance has a positive impact on organization performance significantly and Implementation of Online Application significantly too as moderating between employee performance and organizational performance.

That explains that the driver who has great motivation can increase self-performance and organizational finally. The online application is a new tool in the transportation system and for the taxi driver, so the implementation in the job not have a good place in drivers' perception because of something like bad attitude passenger and many drivers who change to online transportation. The company must have an excellent solution for that obstacle.

\section{Conclusions}

Motivation has a positive impact on employee performance directly, and on organizational indirectly, employee performance has a positive impact on organization performance significantly and Implementation of Online Application significantly too as moderating between employee performance and organizational performance.

That explains that the driver who has great motivation can increase self-performance and organizational finally. The online application is a new tool in the transportation system and for the taxi driver, so the implementation in the job not have a good place in drivers' perception because of something like bad attitude passenger and many drivers who change to online transportation. The company must have an excellent solution for that obstacle. 


\section{Limitations}

Some limitations found in this study can be information to the future study for better, as follow:

1. Using the driver taxi in this study is unique, but based on result especially negative impact of online application, for the future study can be better when also using an ex-taxi driver who changes to online transportation as unit analysis.

2. Based on the result that motivation has a positive impact, for the future study can use the new driver as a unit analysis or make a comparative study between the new driver and long experience driver.

\section{Acknowledgement}

This paper as an assignment of SDAM class and author give the thanks to all lecture in Doctoral Accounting Program at Trisakti University.

\section{References}

Al-Belushi, F. Y., \& Khan, F. R. (2017). Impact of Monetary Incentives on Employee's Motivation: Shinas College of Technology, Oman - A Case Study. International Journal of Management, Innovation \& Entrepreneurial Research, 3(1), pp

Alfandi, A. M., \& Alkahsawneh, M. S. (2014). The Role of the Incentives and Reward System in Enhancing Employee's Performance "A Case of Jordanian Travel and Tourism Institutions." International Journal of Academic Research in Business and Social Science, 4(4), pp

Al-Mzary, M. M. M., Al-Rifai, A. D., \&Al-Momany, M. O. E. (2015). Training and its impact on the performance of employees at Jordanian Universities from the perspectives of employees: the case of Yarmourk University. Journal of Education and Practice, 6(32), pp

Anyango, O. J., \& Muathe. (2017). Toward a Theoretical Model for Work Reorganization, Employees Welfare, and Organization Performance: A Research Agenda. The International Journal of Business \& Management, $5(1), \mathrm{pp}$

Aragon, M. I. B., Jimenez, D. J., \& Valle, R. S. (2014). Training and performance: The mediating role in organizational learning. Business Research Quarterly, pp

Atambo, W.N., Kabare, K., Munene, C., \& Mayogi, E.N. (2013). The role of employee incentives on performance: a survey of public hospitals in Kenya. Global Business and Economics Research Journal, 2(12), pp

Athar, R., \& Shah, F. M. (2015). Impact of Training on Employee Performance (Banking Sector Karachi). IOSR Journal Business and Management, 17(11), Ver. 1, pp

Bhat, Z. H. (2013). Impact of Training on Employee Performance: A Study of Retail Banking Sector in India. Indian Journal of Applied Research, 3(6), pp

Chin, W. W. (1998). The Partial least squares approach for structural equation modeling. In G.A. Marcoulides (Ed.), Modern methods for business research (pp. 295-236). London: Lawrence Erlbaum Associates.

Chin, W.W. (2010). How to write up and report PLS analyses. In V.E. Vinzi, W.W. Chin, J. Henseler, \& H. Wang (Eds.), Handbook of partial least squares: Concepts, methods, and applications in marketing and related fields (pp. 83-97). Berlin: Springer.

Davis, F. D. (1986). A Technology Acceptance Model for Empirically Testing New End-User Information Systems: Theory and Results. Doctoral Dissertation, Sloan School of Management, Massachusetts Institute of Technology.

Davis, F. D. (1989). Perceived usefulness, perceived ease of use, and user acceptance of information technology. MIS Quarterly, 13, 319-340.

Dobre, O. I. (2013). Employee motivation and organizational performance. Review of Applied Socio-Economic Research, 5(1), pp

Eko, W. S. (2015). Manajemen Pengembangan Sumber Daya Manusia.Yogyakarta: PUSTAKA PELAJAR.

Falola, HO, Osibanjo, AO, \& Jojo, SI. (2014). Effectiveness of Training and Development on Employees' Performance and Organization Competitiveness in the Nigerian Banking Industry. Economic Science 7(56), No. $1, \mathrm{pp}$

Gellert, F. J., \& Schalk, R. (2012). The influence of age on perceptions of relationship quality and performance in care service works team. Employee Relations, 34(1)

Gidumal, J. B., \& Gonzalez, S. M. (2011). Maximizing the positive influence of IT for improving organizational performance. Journal of Strategic Information Systems, 20(2011), 461-478

Gilbert, T. F. (1977). Training: The \$100 Billion Opportunity. Training and Development Journal.

Gilbert, T. F., \& Gilbert, M. B. (1977). Knowledge Maps. Morristown: Praxis Technical Series.

Ghozali, I. \& Latan, H. (2015). Partial Least Squares Konsep, Teknik dan Aplikasi Menggunakan Program SmartPLS 3.0 Untuk Penelitian Empiris. Semarang: Badan Penerbit Universitas Diponegoro.

Groen, Bianca A.C., Marc J. F., Wouters, \& Celeste P.M. Wildrom. (2016). Employee participation, performance metrics, and job performance: a survey study based on self-determination theory. Management Accounting 
Research

Hair, J.F., Ringle, C. M., \& Sarstedt, M. (2011). PLS-SEM: Indeed A Silver Bullet. Journal of Marketing Theory and Practice, 19(2), pp 139-150

Hair, J.F., Sarstedt, M., Ringle, C.M., \& Meda, J.A. (2012). An Assessment of the use of Partial Least Squares Structural Equation Modeling in Marketing Research. Journal of The Academy of Marketing Scienc,e 40(1), pp. 414-433

Hameed, A., Ramzan, M., Zubair, H. M. K., Ali, G., \& Arsian, M. (2014). Impact of Compensation on Employee Performance (Empirical Evidence from Banking Sector of Pakistan). International Journal of Business and Social Science, 5(2)

Hatane, S. E. (2015). Employee satisfaction and performance as intervening variables of learning organization on financial performance. Procedia - Social and Behavioral Sciences 211 (2015) 619-628

Hezberg, F. (1964). The Motivation-Hygiene Concept \& Problems of Manpower. Personal Administrator (27), 37

Khan, I., Dongping, H., \& Ahmad, T. (2014). Impact of Attitude on Employee Performance: A Study of Textile Industry in Punjab, Pakistan. World Applied Sciences Journal, 30(x), pp

Kumara, I.W.S.E., \& Utama, I.W.M. (2016). Pengaruh Pelatihan Terhadap Kinerja Karyawan Dengan Mediasi Kepemimpinan Pada Hotel Satriya Cottages Kuta-Bali. E-Jurnal Manajemen Unud, 5(3), 1399-1428.

Marques, A. (2003), A importância das práticas do marketing relacional na formulação e implementação de estratégias competitivas e a influência destas na lealdade dos clientes e na performance: A investigação de um modelo estrutural no contexto empresarial Português. Faculdade de Economia. Coimbra, Universidade de Coimbra. Doutoramento, p. 537.

Mullen, J. E., Kelloway, K., \& Ted, M. (2017). Employer safety obligations, transformational leadership and their interactive effect on employee safety performance. Safety Science, 91, pp.

Nabi, M. N., Islam, M. M., Dip, T. M., Al Hossain, M. A. (2017). Impact of Motivation on Employee Performances: a case study of Karmasangsthan Bank Limited, Bangladesh. Arabian Journal of Business and Management Review 7:1

Nadeem, M., Ahmad, N., Abdullah, M., \& Hamad, N. (2014). Impact of employee motivation on employee performance (a case study of private firms: Mutan District, Pakistan. International Letters of Social and Humanistic Sciences, 36, pp51-58

O'Hagan, S. B. (2017). An exploration of gender, interlocking directorates, and corporate performance. International Journal of Gender and Enterpreneurship

Pawirosumarto, S., Purwanto K. S., \& Muchtar, M. (2017). Factors affecting employee performance of PT. Kiyokuni Indonesia. International Journal of Law and Management, 59(4)

Panjaitan, M. (2015). Pengaruh Insentif dan Motivasi Kerja Terhadap Kinerja Pegawai Pada Kantor Dinas Pertanian Provinsi Sumatera Utara. Jurnal Ilmiah INTEGRITAS, 1(2), pp.

Pfano, M., \& Beharry, A. (2016). The Effect of Modern Office Technology on Management Performance: Durban Westville. Problems and Perspectives in Management, 14(2), pp.

Salem, I. E., \& Abdien, M. K. (2017). Implementation of employee cross-crosstraining during perilous conditions in hotels. Tourism Management Perspective, 23(x), pp.

Sharma, S. (2016). Impact of Training on Employee Performance: Conceptual Study in Contect Motivation and Job Satisfaction in an Organization. International Journal of Emerging Research in Management \& Technology, 5(4)

Sudibyo, Y. A., \& Hiskia, R. F. (2013). The influences of workspace spirituality, organizational factors, and cultural factors on employees performance through organizational commitment. Journal of Operations Management (26), pp. 180-197

Torres, P. M., \& Lisboa, J. V. (2014). E-Commerce strategies and corporate performance: an empirical investigation. Competitiveness Review, 24(5), pp 463-481

Triasmoko et al. (2014). Pengaruh Pelatihan Kerja Terhadap Kinerja Karyawan. Jurnal Administrasi Bisnis, 12,(1), pp.

Vosloban, R. I. (2012). The Influence of the employee performance on the company's growth - a managerial perspective. Procedia Economics and Finance, 3, pp.

Vrom, V.H. (1964). Work and Motivation, New York: Wiley, 331 p.

Wibowo. (2016). Manajemen Kinerja Edisi Kelima. Rajawali Pers

www.bluebirdgroup.com

www.liputan6.com/bisnis/read/3012394/31-perusahaan-taksi-gulung-tikar-dalam-2-tahun 


\section{APENDIX - QUESTIONNAIRE}

\section{Dear Taxi Driver}

I am a student from Trisakti University, for academic purposes are researching the performance of taxi driver and company from employee internal and employee external factors and also the implementation of an online application.

Please be willing the fill in each question by selecting the button available and after finishing, please send the link to other drivers. Thanks.

\section{A. Profile}

1. Driver Number Identity

2. Age :
a. Under 30 s yo
b. 30 s yo up to 40 s yo
c. 41 s yo up to 50 s yo
d. Over than 50 s yo

3. Gender : M / F (choose one)

4. Handphone Number :

5. Last Education :

\section{B. Questionnaire}

Please choose number 1 for "Strongly Disagree" and number 6 for "Strongly Agree" in your opinion from the following statement:

\section{Organizational Performance}

1 The taxi company revenue where I work is higher than other taxi companies

2 The taxi company where I work is famous for being the best in Indonesia

3 Many orders at taxi companies where I work

4 Passenger Services are highly preferred in the Company

5 The company has several types of taxi according to passenger needs

6 Innovation in passenger service is very important for the Company

123456

123456

123456

123456

123456

123456

\section{Employee Performance}

7 The more passengers, the more 123456 prosperous the driver

8 Minimizing operational costs is a 123456 profitable thing

9 I am very happy to drive well and 1233456 make passengers comfortable

10 The value of passengers after 123456 delivery reflects the quality of my driving

11 If it is stuck on the road, I look for ways to not stress during the trip

12 Complaints from passengers made me stressed
Age

13 Old drivers drive wisely

123456

14 Older drivers are more 123456 experienced

\section{Discipline}

15 I always try to be present at work, 123456 unless other things are very important

16 Coming home quickly before time is a detrimental problem while driving

17 If it comes late, the fortune will be 123456 smaller

\section{Motivation}

18 I work well so that my life will be 123456 comfortable in the future

19 I work well, so I do not live in 123456 hardship

\section{Training}

20 The first training helps the driver understand how to work

21 Development employee training 123456 with a specific schedule helps the driver to improve service standards

\section{Incentive}

22 The amount of commission in 123456 driving is important

23 The amount of bonus in driving is 123456 an exciting thing for the driver

24 The driver needs health 123456 allowances in supporting the work.

\section{Implementation of Online}

Application

25 With the online applications, I 1223456 easily receive orders

26 With the online application, I 1223456 easily find a pickup location

27 Online applications help increase 123456 orders

28 Online applications help show 1223456 delivery locations

Thanks, 